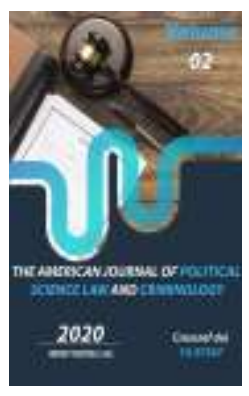

\title{
Regional Mechanisms Against Illegal Drug Trafficking
}

\author{
Shukurov Izzatullo Hikmatullo Ogli \\ Doctoral Student Of The Academy At The Prosecutor General's Office Of The Republic of \\ Uzbekistan
}

Journal Website: http://usajournalshub.c om/index,php/tajpslc

Copyright: Original content from this work may be used under the terms of the creative commons attributes 4.0 licence.

\section{ABSTRACT}

The article examines regional mechanisms of counteracting drug trafficking, as well as means of combating drug addiction at the international level. In addition, it examines theoretical and practical features of the fight against drug trafficking in such organizations as ISESCO, NATO, OSCE, SCO, Western European Union, CIS .

\section{KEYWORDS}

Drugs, ISESCO, NATO, OSCE, SCO, Western European Union, CIS, SCO, crime, drugs, customs, terrorism.

\section{INTRODUCTION}

Establishment of mechanisms for regional cooperation between countries along with universal mechanisms against drug trafficking will contribute to further increase of the efficiency countries' cooperation in this sphere. Today, we can see that both universal and regional systems have been formed [1]. In other words, this system is developing on the basis of regional international intergovernmental organizations specialized in the fight against illegal drugs trafficking.

Regional intergovernmental organizations play an important role in the fight against drug 
trafficking [2] . According to the classification criteria in the context of regional organizations and international organizations can be classified as follows:

- Organizations with general competence, those that coordinate cooperation between their member-states in all spheres - e.g. CIS, the European Union institutions;

- Organizations with specialized competence, aimed at the development of regional cooperation in political, military, economic, financial, trade, healthcare and other specific areas - e.g. ISESCO, NATO.

Regional organizations depending on the scope of geographic coverage can be divided into the following categories:

- Interregional, covering in two or three continents of the world (for example, the OSCE, NATO);

- Regional, international organizations aimed to unite only countries geographically in certain continent (eg, the European Council, the African Union Organization);

- Subregional, international organizations covering countries of a small geographic area (such as Shanghai Cooperation Organization, Western European Union) [3].

Based on whether an organization accept or does not accept new countries, they are divided into open or closed types of international organizations.

Correlation between the volume of powers given to international organizations by member countries can also allow to distinguish the following types:
Coordinative international intergovernmental organizations where the organization itself enjoys the same functions as member states, e.g. CIS;

Supranational international organizations where international organizations have higher authority over member states, such as the European Union.

In the first case, the designation of international organization is intergovernmental cooperation, where decisions referred to the member states, whereas in the second case interstate integration is considered, where their decisions, refer not only governments, but also directly to the citizens of the member-states and legal entities as well.

If we use the above mentioned classification, it is difficult to distinguish international organizations specialized only in the field of fight against illegal drug trafficking. However, fight against illegal drug trafficking is paid a great deal of attention in such anti-crime organizations as CIS, SCO, the EU. The fight against drug trafficking within the framework of these organizations can be transferred to a certain body or special program [4] .

For example, let's consider the European Union's support for the fight against narcotic drugs in Central Asia Program (CADAP-6). On March 1, 2017, Uzbek delegation composed of representatives of the Supreme Court, the Prosecutor General's Office, the Ministry of Internal Affairs, the Ministry of Healthcare and the National Center on Drug Control took part in the conference "Regional policy of 5 Central Asian countries in the field of drugs: Challenges and Solutions", that was held in Bishkek, the Kyrgyz Republic. The event was organized with EU's support within the project "National 
strategy for the fight against drugs" of CADAP6.

Participants of the conference acquainted with the Report on condition of the state policy in the field of drugs in Central Asia, made by experts from the European Union, and exchanged views about the possible measures of further implementation of the program [5] . Another such program is OSCE's project "Ensuring control over drug trafficking and to prevention of its spread" [6] [6, B 95 ].

This project is oriented at improvement of material-technical base of the specialized institutions of the Republic of Uzbekistan, organization of training courses, and information analysis potential. Project implementation also assisted in publishing annual ballots on drug situation in Central Asia. In addition, specialists of law enforcement organizations, lab experts, secretaries of regional committees of Council of Ministers of the Republic of Karakalpakstan, regions and Tashkent city as well as narcologists of narcology cabinets took part in short -term training courses at the educational centers of the European Union. At the moment, the project is also assisting in creation of interinstitutional database of illegal drug circle within the framework of the National Drug Control information-analytical center [7] .

Since 2002, the Center has been closely cooperating with of the United Nations Office on Drugs and Crime's Regional Representative in Central Asia and the OSCE Center of International Programs in preparation of cynologists and dog training. In particular, "BOMCA" project aimed at strengthening the boundaries in Central Asia was carried out by the Regional Representative and the OSCE Center in Central Asia, as well as cynologists of bordering countries were trained on the basis of bilateral agreements. In 10 years, 6 regional training course were held for customs and border services of Kazakhstan, Kyrgyzstan, Tajikistan [8].

One of the regional mechanisms to combat drug resistance is the "Shanghai Cooperation Organization" (SCO), within the framework of which cooperation in economic, political spheres as well as in the fight against terrorism, extremism, separatism and drug trafficking.

Analysis of Shanghai Cooperation Organization's annual meeting reports and signed documents reflect the growing concern on traditional and untraditional obstacles and threats to the development of the area. The very concern pushes them to realize the need of further expansion of the activity range of the organization. Terrorism, separatism, extremism, smuggling of drug and weapon issues required to enlarge the scope of activities and expand of the organization's functions.

During SCO annual summit, particular attention is paid to terrorism, extremism, separatism, as well as drug trafficking. For instance, during the Summit in Moscow on May 29, 2003, the first President of Uzbekistan Islam Karimov stated that international terrorism, radical violent extremism and separatism, fight against drug trafficking and organized crime, without any exaggeration, had become the an important area of activity of the SCO.

Shanghai Cooperation Organization is also paying special attention to this problem. In particular, specialized agency of Regional AntiTerrorism Structure is engaged in not only problems of fight against terrorism, but also against drug trafficking as the main financial source of terrorism. In particular, SCO Regional Anti-Terrorist Structure (RATS) is cooperating 
with the European Union in combatting against Afghan drug trafficking.

According to the press service of the RATS, SCO members' law enforcement authorities strengthened operational cooperation on "heroin information networks" program. Financed by the EU, "heroin information networks" program is a part of counter organized crime program.

According to the data, the largest illegal flow of drugs passes through the territory of Central Asian countries to Russia and from there to Europe. According to estimates, "northern route" transport capacity is 100 tons of powerful drugs a year.

SCO includes Russia, China, Kazakhstan, Kyrgyzstan, Tajikistan and Uzbekistan. The Regional Anti-Terrorist Structure (RATS) has been established within the SCO. Its headquarters is located in Tashkent [9] .

In this direction, SCO closely cooperates with the United Nations too. For example, on March 12, 2018 in Vienna (Austria) within the framework of the 61st session of the Commission on Narcotic Drugs, a joint meeting on the topic "United Nations and Shanghai Cooperation Organization against drugs: common threats, joint actions" was held. The head of the delegation of the Republic of Uzbekistan underlined the importance of measures taken to control drug trafficking and related situation in his speech. [10].

Taking into account situation with drugs in the Central Asian region, there were given effective and practical proposals to stimulate cooperation between the UN and Shanghai Cooperation Organization in the fight against drug threat [11].
On April 2-3, 2018, in Beijing, working group meeting of the heads of Shanghai Cooperation Organization the member states' competent authorities was held to reduce the demand for drugs.

The draft of Concept of the SCO to prevent the abuse of narcotic drugs and psychotropic substances was discussed at the meeting [12] . During the meeting of the working group under chairmanship of the People's Republic of China, competent bodies of the Shanghai Cooperation Organization (SCO) member countries in the fight against drugs took part and discussed plan of actions of SCO for 2018, including improvement of the normative-legal basis of cooperation on issues of prevention the spread of drugs. [13] .

To sum up, analysis of the activities of regional organizations in crime fighting shows that even if the fight against illegal drug trafficking is not their main function, these organizations struggle against illegal drug trafficking through working out specific projects in this direction and their implementation with countries.

International organizations against illegal drug trafficking sector, they also can be distinguished based on generally accepted criteria for classification of international organizations:

\section{1) By activity:}

- Those with general authority designed to coordinate all areas of cooperation between the member states, as well as goals and objectives (e.g. CIS, European Union institutions);

- Particularly authorized, specializing in the field of fight against drugs and crime as a specialized organization (e.g. United Nations Office on Drugs and Crime Department, Interpol, 
World Health Organization, UNESCO within the framework of the fight against drug addiction);

2)

\section{By geographical coverage:}

- Universal, the United Nations and its specialized agencies,

- Interregional, covering a region or continent of the world, that is, two or three (for example, the OSCE, NATO);

- Regional, i.e. international organizations that aim to unite the countries of a particular continent (for example, the Council of Europe, the Organization of African Unity);

- Subregional, international organizations covering the countries of a particular small region (for example, the $\mathrm{SCO}$, $\mathrm{CIS})$;

3) By order of accepting new members:

- Open for new members;

- Closed for new members .

UN International Committee International for drugs control is supposed to be an independent quasi-judicial body that controls the execution of UN's International Conventions on drug trafficking. This unit was established in 1968, and is regulated by 1961's the Single Convention "On Drugs". The International Committee established close cooperation with UN Crime and Drug Office, World Health Organization, World Customs Organization, Interpol and direct contacts the drugs with Drug Commission.

The United Nations Office on Drugs and Crime is one of the leading organizations in the world to fight against drug trafficking organized crime [14] . The organization provides legal and technical assistance to countries in the prevention of terrorism by solving problems in health care, security and justice. It is considered as the best organization in UN system with great potential and experience in struggling against terrorism [15] . In particular, it has wide practical experience in strengthening the rule of law, improvement of criminal law, crime prevention, fighting against international organized crime, legalization of illegal incomes, corruption and international cooperation in these areas.

\section{CONCLUSION}

In conclusion, we can say that, first of all, the UN and its Office on Drugs and Crime are in the center of the universal scale international institutional system and its fight against illegal drug trafficking. This body is currently coordinating the fight against illegal drug trafficking in the world.

Secondly, analysis of the activities of regional organizations in crime fighting shows that even if the fight against illegal drug trafficking is not their main function, these organizations struggle against illegal drug trafficking through working out specific projects in this direction and their implementation with countries.

\section{REFERENCES}

1. Akhmedov G. A., Kadyrov M. M. Drug addiction. Crime\& Responsibility. - T.: Uzbekistan, 1989. -p.4.

2. Saidov A. Kh. International law. Textbook. - T .: Adolat, 2001. - p. 84

3. Tropinoy T.L. WORLD DRUG REPORT 2018 / Translation Tropinoy T.L. 2019g. p. 87

4. Ibragimova S. Combating international terrorism within the framework of the Shanghai Cooperation Organization. // Life and Law № 2, 2004. -p.30

5. Regional Conference on Drug Policy: Threats and Solutions in 5 Central Asian 
Countries. (http://www.ncdc.uz/uz/presstsentr/mezhdunarodnye-vstrechi-imeropriyatiya/2017/03/518/invert ).

6. Information bulletin on drug trafficking. Central Asian region. - Tashkent, 2013. - p. 95.

7. National Information and Analysis Center on drugs under the Cabinet of Ministers of the Republic of Uzbekistan.International projects and programs.

(http://www.ncdc.uz/uz/mezhdunarodno e-sotrudnichestvo/206/

8. Official website of the State Customs Committee of the Republic of Uzbekistan (http://www.customs.uz/uz/events/speec hes_presentations_news/1196

9. The SCO and the EU work together to combat Afghan drug trafficking. https://sputniknewsuz.com/society/20151211/1298056.html .

10. National Information and Analysis Center for Drug Control under the Cabinet of Ministers of the Republic of Uzbekistan. International projects and programs.

11. National Information and Analysis Center for Drug Control under the Cabinet of Ministers of the Republic of Uzbekistan. International projects and programs. http://www.ncdc.uz/uz/mezhdunarodnoe -sotrudnichestvo/206/

12. National Information and Analysis Center for Drug Control under the Cabinet of Ministers of the Republic of Uzbekistan. International projects and programs. http://www.ncdc.uz/uz/mezhdunarodnoe -sotrudnichestvo/206/

13. Abdirov N.M., Mami K.A., Sarsekov B.S. Criminal legal aspects of fighing against crimes related to drugs (textbook) Almaty, 1998. - p.23.

14. Muxamedov F.E. International cooperation in fighting against drug trafficking. // J. International relations: politics, economics, law. Scientific- theoretical journal, -T.; UWED, 2008, №1. p.63-69.

15. Omigov V.I. The concept of illegal drug trafficking and the role of internal organs in the development of the Russian Federation. Perm. 1994. - p.12 